\title{
Antibacterial Finishing of Cotton Textiles with Extract of Citrus Fruit Peels
}

\author{
Asaye Dessie Wolela* \\ Department of Textile Engineering, Wollo University, Ethiopia
}

Submission: October 30, 2019; Published: January 07, 2020

*Corresponding author: Asaye Dessie Wolela, Department of Textile Engineering, Kombolcha Institute of Technology, Wollo University, Kombolcha, Ethiopia

\begin{abstract}
The objective of this study is to explore, evaluate and compare the antibacterial activity of a cotton fabric treated with essential oils extracted from green, orange \& black (a mixture of both green and orange) lemon peel (Citrus limon). The Citrus limon peel is rich in nutrient such as flavonoid and essential oil that can be used for antimicrobial activity. The finishing agent, lemon peel extract was extracted by treatment with methanol using steam distillation techniques. The antimicrobial activities were evaluated against Staphylococcus aureus (gram-positive) and Escherichia coli (gram-negative) bacteria by zone of inhibition measurement. Cotton finished with green lemon peel extract showed strong antimicrobial activities against Staphylococcus aureus $(24-30 \mathrm{~mm})$ and Escherichia coli $(22-26 \mathrm{~mm})$ bacteria as compared to orange and black lemon. Black (50\% green and 50\% orange) lemon peel extract showed better antimicrobial activities against Staphylococcus aureus (18-26mm) and Escherichia coli $(18-25 \mathrm{~mm}$ ) bacteria than the orange lemon peel. In addition to this, the durability of the natural finishing agent on cotton was measured before or after washing and has got the same effect. From this study, it was revealed that citrus lemon have better, durable antibacterial potential with the green lemon peel extract having a more efficient effect compared to others
\end{abstract}

Keywords: Antibacterial; Lemon peel; Essential oil; Zone of inhibition; Cotton fabric

\section{Introduction}

The antimicrobial finishing process imparts the ability, to textile substrate, to inhibit the growth (-static) or reproduction of at least some types of microorganisms or to kill (-cidal) at least some types of microorganisms"

[1-3]. Therefore, an antimicrobial finish should be capable to kill the microbes by breaching the cell wall or alter cell membrane permeability, obstructing the synthesis of proteins of microbes, blocking enzyme production necessary for microbes' food [1]. The major use of the antimicrobial was in the medical and the pharmaceutical industry. However, newer applications are possible. The textile fibers are these days increasingly treated with antimicrobial reagents. The other examples include the applications in food packaging and food storage, and medical, surgery and hygienic products etc [4-6]. With the improvement of life standards, the demand of hygienic products is increasing for biocidal finishes in textiles (sports-wears, undergarment, bedlinen) and water filtration. The antibacterial finish treatment has become vital area of medical, surgical and healthcare activities due potential pathogenic microorganisms present in hospital environment and cause cross-infection diseases [7-11]. The types of micro-organisms include different kinds of organisms such as virus, bacteria, unicellular plants and animals, certain algae and fungi [12]. Classification in bacteria family is "gram- positive, gram-negative, spore bearing or non-spore bearing type". Some of the bacteria are of pathogenic nature that may cause infections to human [13].

A gram-positive bacterium contains peptidoglycan and teichoic acid, peptidoglycan comprises of $90 \%$ of cell walls and made of amino acid and sugar. One example of gram-positive bacteria is Staphylococcus aureus (S.aureus) that is in form of pair, short chain or graphic like cluster. Its size range is $0.5 \mu \mathrm{m}$ to $1.0 \mu \mathrm{m}$ and grows in temperature range of 35 to $40^{\circ} \mathrm{C}$. S aureus is major cause of cross infection in hospital environment and 19\% of total surgical infection. It's also responsible for boils and also cause scaled skin infections. Gram-negative bacteria are firm to reduce as compared to gram positive bacteria for the reason that of extra cell walls. An example of gram-negative bacteria is Escherichia coli (E. coli); its shape is similar to a bacillus and dwell in intestine of human. E. coli can be proliferated during eating and/or usage of raw food stuff [13]. Antimicrobials control the growth of microorganisms and their negative effects of odour, staining and deterioration. Antimicrobial finishing prevents or inhibits the growth of microorganisms or microbes. The enormous majority of antimicrobials work by leaching or moving from the surface on which they are applied [14-16]. Most 
modern antimicrobial finished textiles are based on synthetic products, and current consumer demands must be correlated with obtaining environmental friendly final products. Conventional antimicrobial finishing includes treatment with quaternary ammonium compounds, triclosan, N-halamines, poly biguanides, nanoparticles of noble metals (nanosilver treatment) and metal oxides $[17,18]$ but also treatment with titanium oxide doped with various elements for photocatalytic and antimicrobial induced properties.

New trend in antimicrobial finishing promotes plant-based dyes [19] over synthetic ones that can also act as antimicrobial agents [20]. Plant extracts provided an attractive source of eco- friendly antimicrobial finish. The natural cure using plant extracts is increasingly receiving interest in the development of antimicrobial textiles.

Plant extracts can be used as finishing agents during textile processes or can be encapsulated for inducing controlled release properties (acacia based capsule wall filled with herbal extracts [21]. Current researches regarding use of various plants extracts for the treatment of antimicrobial finished fabrics include functionalization of $100 \%$ cotton bed linen fabric with neem (Azadirachta indica) and Mexican daisy extracts [22], fabrics treated with turmeric rhizomes extract (Curcuma longa) pomegranate fruit rinds extract (Punica granatum), aloe vera extract [23], tea oil, eucalyptus oil, tulsi leaves extract, with high antimicrobial efficiency [24] against a series of fungi and Gram-positive and Gram-negative bacteria [25]. Beside extracts treatment, bioactive functionalisation of textile fibers includes compounds such as phenolic and polyphenols, alkaloids, lectins, poypeptide, polyacetylene, terpenoids etc [26]. Although the antimicrobial properties of various plants extracts has been thoroughly researched, the antimicrobial active functionalization of textile materials using plants extracts still require intensive documentation.

Lemon (Citrus sinensis) peel is an agro-horticultural waste produced in huge quantities from various fruit processing industries. It is normally discarded and dumped in the environment that can create environmental concerns $[27,28]$. Citrus limon belongs to Rutaceae family; its common name is lemon and this originated from South East Asia, probably in India or Southern China. Lemon is a pale yellow, elliptical or globe shaped berry fruit. Citrus fruit, in general contain sugar, polysaccharide, organic-acid, lipids, carotenoids, vitamins, minerals, flavonoids, bitter lemonoids and volatile compounds. Lemon is a good source of potassium, calcium \& vitamin C. Limon or lime juice have been reported to exhibit antimicrobial activity against Vibrio cholera $[29,30]$. Citrus by-products, if utilized fully, could be major sources of phenolic compounds. The peels, in particular, are an abundant source of natural flavonoids, and contain higher amount of phenolics compared to the edible portions. It has been reported that the contents of total phenolics in peels of lemons, oranges, and grapefruit were $15 \%$ higher than those in the peeled fruits $[27,31]$. Flavonoids in citrus are a major class of secondary metabolites. The peel contains the highest amount of flavonoids than other parts and those flavonoids present in citrus fruits belong to six peculiar classes according to their structure. They are: flavones; flavanones; flavonols; is of lavones; anthocyanidins and flavanols [31].

Recent research suggests that citrus fruits possess another health benefit phytochemicals called limonoids, highly oxygenated triterpenoid. Citrus limonoids appear in large amounts in citrus juice and citrus tissues as water soluble limonoid glucosides or in seeds as water insoluble limonoid aglycones. The limonoid aglycones are responsible for the development of delayed bitterness in citrus and are converted to the non-bitter limonoid glucosides during fruit maturation [27]. The objective of the present work is imparting antimicrobial finish on cotton by using natural fruit peel extract to fabric and to reduce the effect of microorganism on human body and a fabric.

\section{Materials and Methods}

\section{Materials and Chemicals}

Lemon fruits (Citrus sinensis) were obtained from local Ethiopian market. The lemon peels were collected immediately after the fruit was peeled. Full bleached plain cotton fabric with 24 ends per inch, 18 picks per inch and having a GSM of 142g/ $\mathrm{m}^{2}$ supplied by Kombolcha Textile Share Company was used. All chemicals used were of analytical-reagent grade and obtained from Chemical Engineering Laboratory (KIOT, Ethiopia).

\section{Experimental Procedure}

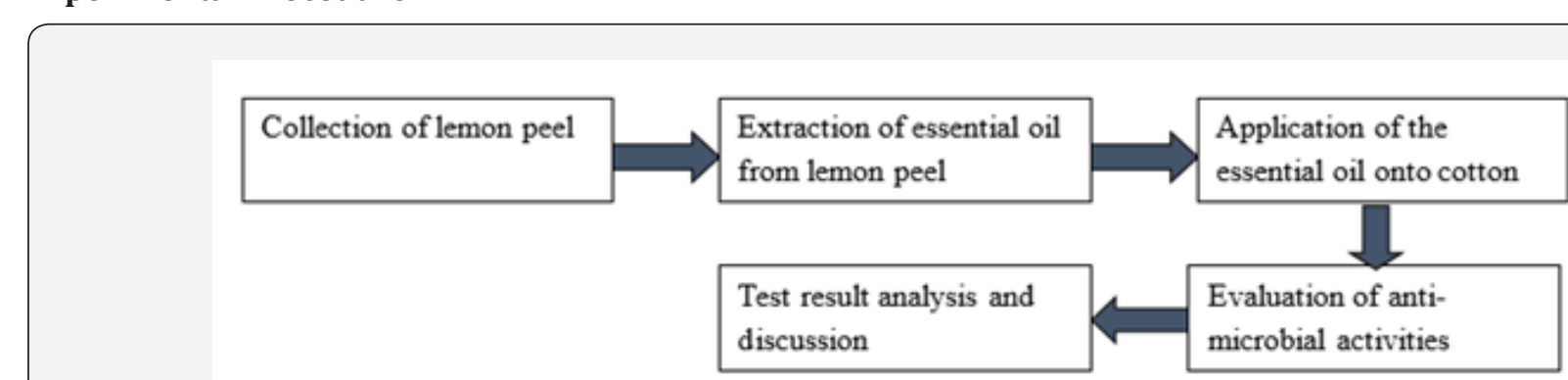

Figure 1: Experimental procedure 
In this study the following experimental procedure was followed to finishes cotton with ant-bacterial by treatment with essentials oils of lemon peels (Figure 1).

\section{Preparation of lemon peel}

The lemon peels were obtained from the local juice vendors in Kombolcha (Ethiopia). The fruits collected from local market must be fresh and not affected bacteria before then it will change the properties of microbes during application and testing. The peels were sorted, cleaned and washed in sterile distilled water, air dried and peeled off further; the peels were dried in sun, packed in envelops for drying in hot air oven at $65^{\circ} \mathrm{C}$ for 3 days and used as raw material for the extraction of antimicrobial compounds.

\section{Methods of Extraction of Essential Oil}

Essential oils were obtained by steam distillation from lemon peels. Steam distillation was preferred to direct extraction by heating, in order to avoid loss and denaturation of constituent chemicals. The cotton fabric was treated by impregnation with essential oils of orange and green colored lemon peel separately. In this study three different essential oils was extracted from orange, green and black (mixture of orange and green) lemon peel (Table 1).

Table 1: Extraction conditions of essential oil from Lemon Peel.

\begin{tabular}{|c|c|c|c|c|c|c|c|}
\hline No. & Sample & $\begin{array}{c}\text { Weight } \\
\mathbf{( g m})\end{array}$ & $\begin{array}{c}\text { Volume of } \\
\text { Water }(\mathbf{m l})\end{array}$ & Temperature $\left({ }^{\circ} \mathbf{C}\right)$ & $\begin{array}{c}\text { Time of heating } \\
(\mathbf{m i n})\end{array}$ & Methanol (m) & $\mathbf{p H}$ \\
\hline 1 & Green Peel Powder & 100 & 600 & 100 & 75 & 10 & $6-\mathrm{Apr}$ \\
\hline 2 & Orange Peel Powder & 100 & 600 & 100 & 75 & 10 & $6-\mathrm{Apr}$ \\
\hline 3 & Black Peel Powder & 100 & 600 & 100 & 75 & 10 & $6-\mathrm{Apr}$ \\
\hline
\end{tabular}

\section{Extraction Mechanism of Essential Oil from Lemon Peel}

A green and orange colored lemon was used in this study to extract essential oil for coating of cotton fabric in order to impart antibacterial finish to cotton. Steam distillation techniques were used for extraction of the essential oils from lemon. The essential oils were separated from water using density separator methods. The extraction process for the green lemon and orange lemon was presented in (Figures 2\&3) respectively.

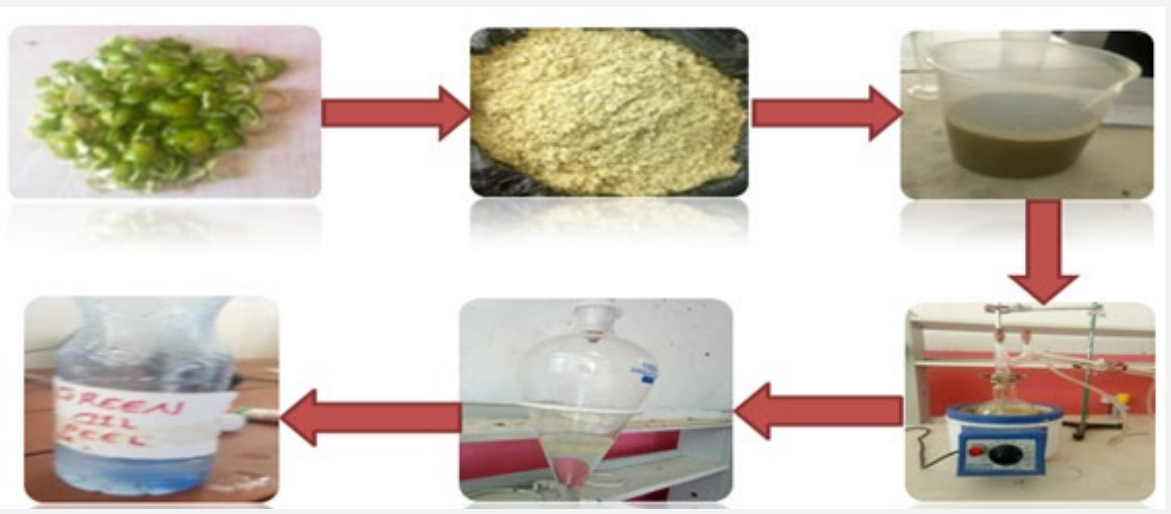

Figure 2: Extraction process of essential oils from green lemon peel.

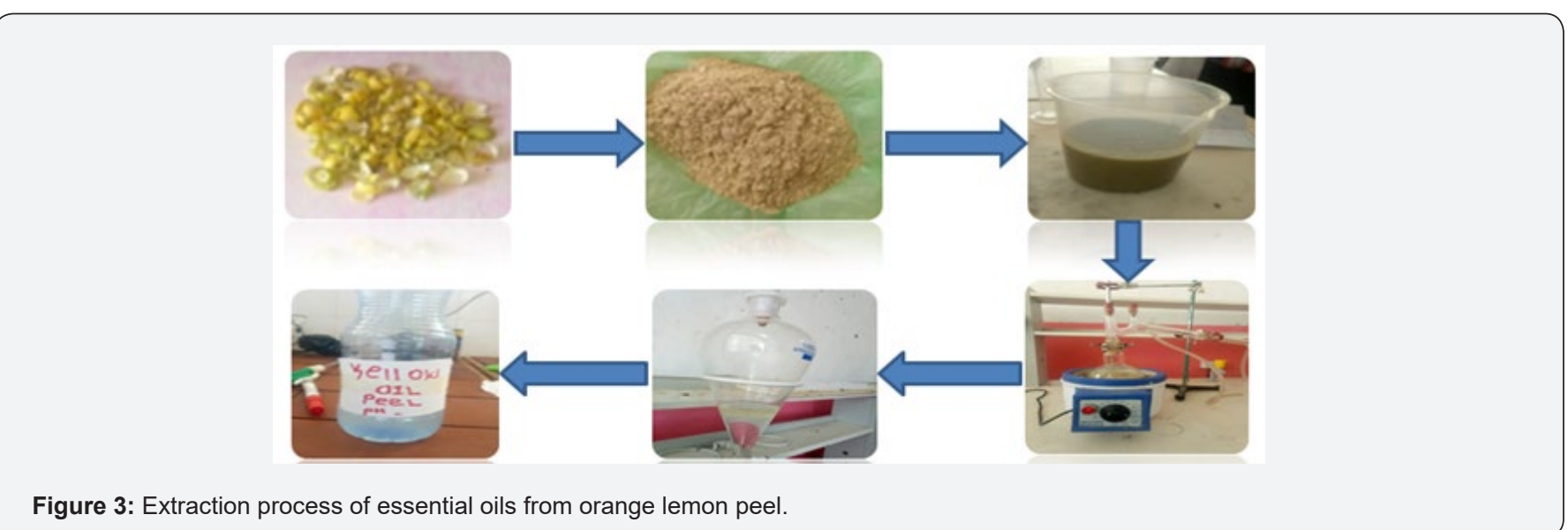

Figure 3: Extraction process of essential oils from orange lemon peel. 


\section{Optimization of Application Conditions}

Pad-dry-cure technique was used in this study to apply the extracted essential oils onto cotton fabric. Optimization of the pad-dry-cure process was done by varying squeezing pressure, drying temperature, drying time, curing temperature and curing time during the application of the essential oils on cotton. For finishing of the extracted natural antimicrobial agent on cotton optimization of application conditions were tried at $60,70,80$, 90 and $100^{\circ} \mathrm{C}$ of drying temperature; $3,5,7,9$ and 11 minutes of drying time; $120,130,140150$ and $160^{\circ} \mathrm{C}$ of curing temperature; $1,2,3,4$ and 5 seconds of curing time. This optimization process was done separately for green, orange and black lemon peel types. Throughout this study, all the samples and results presented are at the optimized applications conditions after a number of trials.

\section{Evaluation of Antimicrobial Activities}

The antimicrobial activity of the samples was tested against E.coli as gram negative bacteria and S.aureus as gram-positive bacteria. The antibacterial activity was tested by means of liquid (turbidity evaluation) and solid medium (agar diffusion) antibacterial using nutrient broth medium $[32,33]$. Antibacterial finishes on cotton fabric was assessed according to AATCC 1002004 standard test method. Test specimens were cut in $4.8+0.1 \mathrm{~cm}$ diameter using a steel die. $100 \mu$ l working culture inoculated test specimens, individually in sterile Petri plates. After inoculation, specimen were placed screw cap jar contained $100 \mathrm{ml}$ neutralizing agent. The toxicity of neutralizing agent against tested organisms was reexamined and no toxicity was determined. Jars were shaked vigorously for one minute, serial dilutions were made. From each of three suitable dilutions, $0.1 \mathrm{ml}$ liquid was drawn and transferred to TSA [34]. The number of survivors was determined after 48 hour incubation at $37^{\circ} \mathrm{C}$ by counting the colonies as colony forming units per millimeter $(\mathrm{CFU} / \mathrm{ml})$ using a colony counter device (Acolyte Super colony Counter, Symbiosis). Furthermore, additional jars were prepared to provide information about the bactericidal activity of treatment over contact period (60 minutes).

Durability is tested by two ways, by washing and by zone of inhibition. The durability of antimicrobial activity by washing

Table 2: Optimized finishes application parameters.

\begin{tabular}{|c|c|c|c|c|c|c|c|}
\hline \multirow{2}{*}{ No. } & \multirow{2}{*}{ Extract Source } & \multirow{2}{*}{ Concentration(\%) } & \multirow{2}{*}{ Pick-up \% } & \multicolumn{2}{|l|}{ Dry } & \multicolumn{2}{|c|}{ Cure } \\
\hline & & & & $\begin{array}{c}\text { Temperature } \\
\left({ }^{\circ} \mathrm{C}\right)\end{array}$ & $\begin{array}{l}\text { Time } \\
\text { (min) }\end{array}$ & $\begin{array}{c}\text { Temperature } \\
\left({ }^{\circ} \mathrm{C}\right)\end{array}$ & $\begin{array}{l}\text { Time } \\
\text { (min) }\end{array}$ \\
\hline 1 & Green lemon & $10 \mathrm{~g} / 100 \mathrm{ml}$ & 80 & 70 & 5 & 140 & 3 \\
\hline 2 & Orange lemon & $10 \mathrm{~g} / 100 \mathrm{ml}$ & 80 & 70 & 5 & 140 & 3 \\
\hline 3 & Black lemon & $10 \mathrm{~g} / 100 \mathrm{ml}$ & 80 & 60 & 7 & 150 & 2 \\
\hline
\end{tabular}

is one of the major concerns of textile researchers and users because textiles are subjected to frequent laundering. The antimicrobial activity of the finished samples was evaluated after being subjected to several wash cycles by ISO: 6330.2012E. In this investigation 5 times washing cycles was used for durability test throughout the whole observation. The content of lemon (Citrus Limon) peel in antimicrobial textile before or after washing was measured and has got the same effect [35]. This is the reason that the antimicrobial textile treated with lemon (Citrus Limon) peel had good antimicrobial ability after 5 times washing cycles and also implied that even only small quantity of essential oil extracted from lemon peel existed on fabrics would offer a good inhibition to E coli and S aureus.

\section{Results and Discussion}

In this research work, the antibacterial activities of orange and green colored lemon peel extract were determined and compared by finishing cotton fabric. The result shows the antimicrobial activity on cotton fabric after 5 washing cycles. The gram positive and gram-negative bacteria were taken to observe their effectiveness and since they behave differently for citrus lemon finishes.

\section{Extraction of the Essential Oil}

The same procedure and parameters were used to extract the essential oils from the green and orange colored lemon. 10 grams of each plant materials were dissolved separately in $100 \mathrm{ml}$ of distilled water with $10 \mathrm{ml}$ of methanol and heated at $100^{\circ} \mathrm{C}$ for 75 minutes. In this steam distillation technique of finishing agent extraction the essential oil was separate from water using density separator.

\section{Optimization of the Application Conditions}

Coating of cotton with natural finishing agent obtained from lemon peel extract were carried out at different application conditions in order to determine the maximum inhibition zone and minimum scorching of the fabric. More effective antibacterial activities were obtained at the optimal parameters in the pad-drycuring process and the results were presented in Table 2. 


\section{Antibacterial Activity of Lemon (Citrus Limon) Peel Extract}

The lemon (Citrus Limon) peel extract were determined for their antibacterial activity against E. coli and S.aureus using muller hinton agar (MHA) method (Figure 4). Diameter of inhibition zone of lemon (Citrus Limon) peel extract was shown in Table 3. From Table 3 and Figure 5, it was observed that the antibacterial activities of green lemon peel extract finished cotton showed higher effectiveness in both gram-negative (E.coli) and gram-positive (S.aureus) than orange and black lemon. (Figure $5 \& 6)$ indicate the maximum and minimum zone of inhibitions against both types of bacteria respectively. Cotton sample which

Table 3: Inhibition zone of lemon (Citrus Limon) peel extract. was finished with green lemon peel is more effective under E.coli types of bacteria by $22-26 \mathrm{~mm}$ zone of inhibition and under S.aureus bacteria by $24-30 \mathrm{~mm}$ zone of inhibition. This result showed that maximum zone of inhibition against both types of bacteria was observed by finishing of cotton with green lemon peel extract. However, the antimicrobial activity of black (mixture of green and orange) lemon peel extract finished cotton sample showed better effect than the orange lemon peel extract treated cotton in both under E. coli types of bacteria by $18-25 \mathrm{~mm}$ and under S.aureus bacteria by $18-26 \mathrm{~mm}$ zone of inhibition. The black sample which compose a mixture of $50 \%$ green and $50 \%$ orange lemon peel was more effective than $100 \%$ orange lemon because of the combinational effect.

\begin{tabular}{|c|c|c|c|}
\hline & \multicolumn{2}{|c|}{ Antibacterial activity diameter of inhibition zone (mm) } & S. aureus \\
\hline No. & Sample type & E. coli & $24-30$ \\
\hline 1 & Green Lemon & $22-26$ & $20-24$ \\
\hline 2 & Orange Lemon & $17-21$ & $18-26$ \\
\hline
\end{tabular}

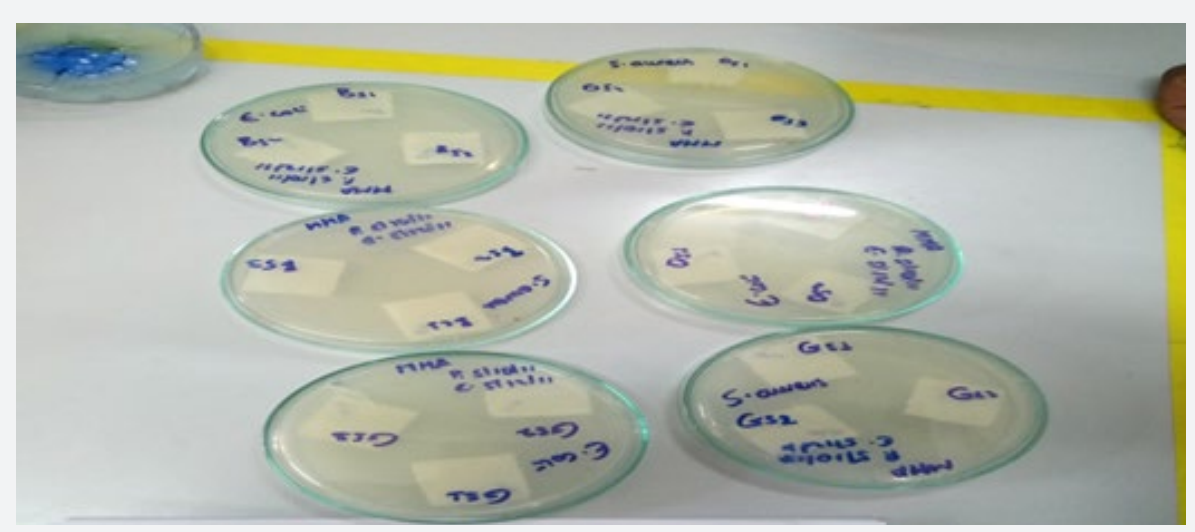

Figure 4: The antibacterial activity of lemon peel extract against E.coli and $S$ aureus bacteria.

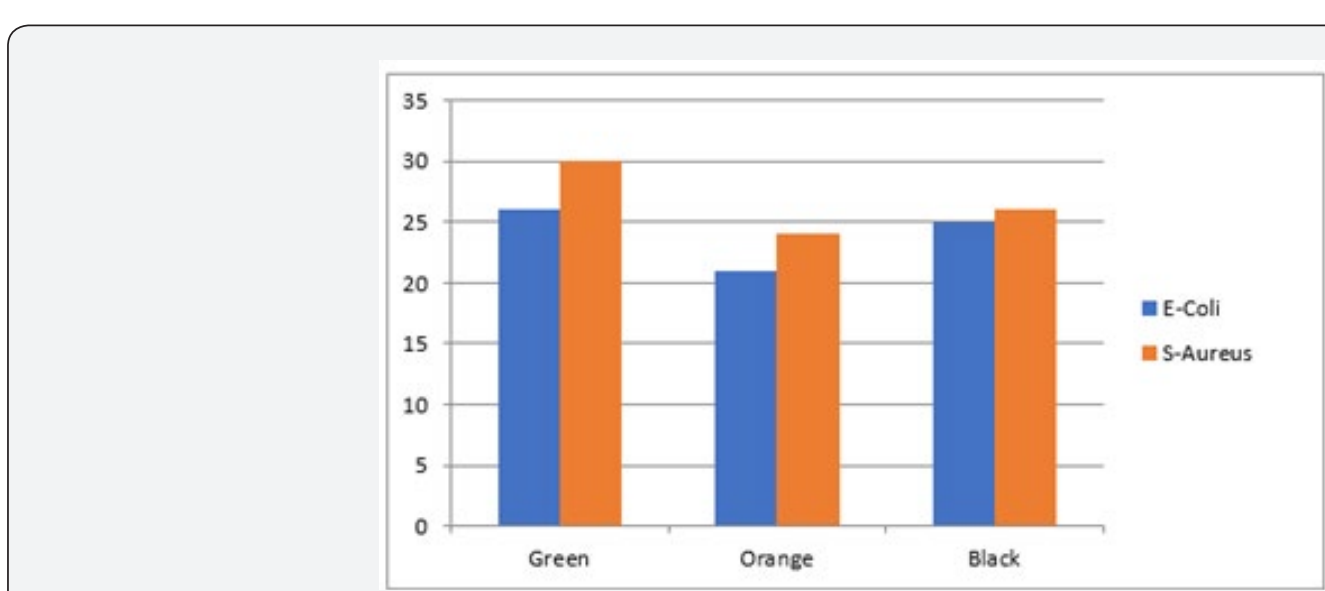

Figure 5: Maximum zone of inhibition. 


\section{Conclusion}

In this study, the antibacterial activities of green, orange and black colored lemon was discussed and compared. The result shows that the coating of cotton using lemon peel extracts have good antimicrobial activity against Escherichia coli and Staphylococcus aureus bacteria. Green lemon peels extract finished cotton showed strong antimicrobial activity against these bacterial. Finishing of cotton using natural plant products waste like lemon peel has high potential to exhibit antimicrobial activity.

\section{Conflict of Interest}

The authors declare that no conflict of interest.

\section{References}

1. Nadeem Afraz, Faheem Uddin, Uzma Syed and Arshad Mahmood (2019] Antimicrobial finishes for Textiles. Curr Trends Fashion Technol Textile Eng 4(5): 1-8.

2. Blackburn R (2004) Life cycle analysis of cotton towels: impact of domestic laundering and recommendations for extending periods between washing. Green Chemistry 6(7): 59- 61.

3. Huang W, Leonas Karen K (1999) One-Bath Application of Repellent and Antimicrobial Finishes to Nonwoven Surgical Gown Fabrics. Textile Chemist \& Colorist 31(3): 11-16.

4. Holme Ian (2007) Innovative technologies for high performance textiles. Color Technol 123(2): 59-73.

5. Uddin Faheem (2004) Technical Textiles: Opportunities. Dawn, Pakistan.

6. Gupta D (2007) Antimicrobial treatments for textiles. Indian Journal of Fibre \& Textile Research. 32(2): 254-263.

7. Horrocks R (2000) Handbook of Technical Textiles. In: A Richard Horrocks, Subhash C Anand (2016) $1^{\text {st }}$ (edn)., Woodhead Publication Ltd and CRC Press LLC, UK, 1: 1-394.

8. Hernandez JR (2017) Applications and Current Status of Antimicrobial Polymers. Polymers against Microorganisms. Springer International Publishing: 255-278.

9. Heine E (2007) Antimicrobial Functionalization of Textile Materials In: $1^{\text {st }}($ edn)., Multifunctional Barriers for Flexible Structure, Springer Berlin Heidelberg, USA, pp. 23-38.

10. Eberhardt MD, Jessie H Chen Yu, Doris H Kincade (2011) Antibacterial and laundering properties of AMS and PHMB as finishing agents for healthcare workers uniforms. Clothing and Textiles Research Journal 25(3): 258-272.

11. Francois NR, Jeanne Doré, Jean Freney H, Bernard Coronel, Jean-Yves Dusseau (2006) Evaluation of Antibacterial Properties of a Textile Product with Antimicrobial Finish in a Hospital Environment. Journal of Industrial Textiles 36(1): 89-94.

12. Ramachandran T, Rajendrakumar Kumar, Radhai Rajendran (2004) Antimicrobial textiles-an Overview. IE (I) Journal-TX 84(2): 42-47.

13. Anand S (2001) Medical Textiles. In: $1^{\text {st }(e d n) ., ~ W o o d h e a d ~ P u b l i s h i n g ~}$ Ltd, UK, pp: 1-256.

14. Nalankilli Govindan, Kalkidan Tadesse (2018) Antimicrobial Finishing of Cotton with Extracts of Solanum Incanum Fruit. International Research Journal of Engineering and Technology 4 (8): 2204-2210.
15. Schulz S, Brankatschk R, Dumig A, Kogel-Knabner I, Schloter M, et al. (2013) The role of microorganisms at different stages of ecosystem development for soil formation. Biogeosciences 10 (6): 3983-3996.

16. Reza Ghorbani, Carlo Leifert, J Zarb, A Koocheki (2005) The Importance of Microorganisms in Organic Agriculture. Outlooks on Pest Management 16(2): 52-55.

17. Ovidiu Iordache, Andreea Cozea, Elena Vărzaru, Elena Stoica, Corneliu Platon, et al. (2016) Antimicrobial Activity of textiles treated with Rosemary and Orange Essential Oils against a selection of Pathogenic Fungi. Scientific Bulletin. Series F. Biotechnologies 20(7): 362-369.

18. Thilagavathi G, Kannaian T (2010) Combined antimicrobial and aroma finishing treatment for cotton, using microencapsulated geranium (Pelargonium graveolens L.) leaves extract. Indian Journal of Natural Products and Resources 1(3): 348-352.

19. Iuliana Dumitrescu, Padma S Vankar, Jyoti Srivastava, Ana Maria Mocioiu, Ovidiu Iordache (2012) Dyeing of cotton, silk and wool with Bixaorellana in the presence of enzymes. Industrial textile 63(6): 327333.

20. Lee LH, Hwang EH, Kim (2009) Colorimetric assay and antimicrobial activity of cotton, silk and fabrics dyed with Peony, Clove, Coptischinensis and Gallnut Extracts. Materials 2(1): 10-21.

21. Lazko Z, Popineanu Y, Legrand J (2004) Soy glycinin microcapsules by simple coacervation method. Colloids Surfaces B: Bio Interfaces 37(12): 1-8.

22. Tilagavathi G, Krishna Bala S (2007) Microencapsulation of herbal extracts for microbial resistance in healthcare textiles. Indian Journal of Fibre \& Textile Research 32(3): 351-354.

23. Jothi D (2009) Experimental study on antimicrobial activity of cotton fabric treated with aloe gel extract from Aloe vera plant for controlling the Staphylococcus aureus (bacterium). African Journal of Microbiology Research 3(5): 228-232.

24. Joshi M, Wazed Ali S, Purwar R (2009) Ecofriendly antimicrobial finishing of textiles using bioactive agents based on natural products. Int J Fibre Text Res 34(3): 295-304.

25. Arsene AL, Rodino S, Butu A, Petrache P, Iordache O, et al. (2015) Study on Antimicrobial and Antioxidant Activity and Phenolic Content of Ethanolic Extract of Humulus Lupulus. FARMACIA 63(6): 851-857.

26. Cowan MM (1999) Plant Products as Antimicrobial Agents. Clin Microbiol Review 12(4): 564-582.

27. Gupta S, Gupta C, Prakash D, Garg AP (2017) Comparative Study of Antimicrobial Effects of Lemon Oil and Peel Extract against FoodSpoilage Microbes. J Nutrition Health Food Sci 5(6): 1-5.

28. Rafiq S, Kaul R, Sofi SA, Bashir N, Nazir F, et al. (2016) Citrus peel as a source of functional ingredient: A review. Journal of the Saudi Society of Agricultural Sciences 17(4): 351-358.

29. Amengialue OO, Oviasogie EF, Omoigberale MNO, Omoregie BO, Okoro TC (2016) Evaluation of Antimicrobial Potential and Phytochemical Screening of Citrus Lemon. European Journal of Advanced Research in Biological and Life Sciences 4(2): 35-43.

30. Tomotake H, Koga T, Yamato M, Kassu A, Ota F (2006) Antimicrobial activity of citrus fruit juice against Vibrio species. J Nutr Sci Vitaminol (Tokyo) 52(2): 157-60.

31. Sawalha SMS, Arráez-Román D, Segura Carretero A, Fernández Gutiérrez A (2009) Quantification of main phenolic compounds in sweet and bitter orange peel using CE-MS/MS. Food Chemistry 116 (2): 567-574. 
32. Mohamed Fawzy Rehan, Nayera Abdel-Wahed, Amr Farouk, Manal El-Zawahry (2018) Extraction of valuable compounds from orange peel waste for advanced functionalization of cellulosic surfaces. ACS Sustainable Chemistry \& Engineering. 6(5): 5911-5928.

33. Ibrahim NA, Mohammed M, Farid MA, Abdel-Wahed NA (2015) Chemical composition, antimicrobial and antifungal activities of essential oils of the leaves of Aeglemarmelos (L.) Correa growing in Egypt. Journal of Applied Pharmaceutical Science 5(2): 1-5.
34. Syed Qutaba Bin Tariq, Lubna Syed, Li Zhaoling (2017) Evolution of eco-friendly antimicrobial finishes extracted from citrus fruits peel for textile cotton fabric with furtherance domestic washing. International Journal of Scientific \& Engineering Research 8(10): 973-979.

35. Alhoi Hendry Henderson, Edy Fachrial, I Nyoman Ehrich Lister (2018) Antimicrobial Activity of Lemon (Citrus limon) Peel Extract Against Escherichia coli. American Scientific Research Journal for Engineering, Technology, and Sciences 39(1): 268-273.
Your next submission with Juniper Publishers will reach you the below assets

- Quality Editorial service

- Swift Peer Review

- Reprints availability

- E-prints Service

- Manuscript Podcast for convenient understanding

- Global attainment for your research

- Manuscript accessibility in different formats

( Pdf, E-pub, Full Text, Audio)

- Unceasing customer service

Track the below URL for one-step submission https://juniperpublishers.com/online-submission.php 